\title{
ISOLATION OF A NEW MORAXELLA FROM A CORNEAL ABSCESS
}

\author{
R. G. A. Sutton, M. F. O'Keeffe, M. A. Bundock, \\ J. Jeboult AND M. P. Tester \\ School of Public Health and Tropical Medicine, University of Sydney, and the \\ Commonwealth Health Laboratory, Lismore, N.S.W., Australia
}

THE purpose of this report is to record the isolation of an unusual Gram-negative bacillus from a human eye infection. The organism is provisionally classified as a strain of Moraxella.

The patient, a male Australian aboriginal, aged $52 \mathrm{yr}$, was a pensioner suffering from chronic bronchitis. When first seen (14 Jan. 1970) he had an enormous corneal abscess and ulceration, occupying two-thirds of the corneal surface; this was accompanied by a hypopyon and severe iritis with posterior synechiae. He was admitted to hospital and, after an abortive attempt to dilate the pupil, was treated with ampicillin $500 \mathrm{mg}$ 6-hourly, Neosporin (Burroughs Wellcome and Co.) eyedrops 2-hourly, and atropine eyedrops three times daily. In hospital the ulcer began to heal from the edges, but the centre became ectatic and on 22 Jan. 1970 a conjunctival flap was placed over the ulcer. This led to a slow cure, so that by $25 \mathrm{Feb} .1970$ there was only a large corneal scar corresponding to the site of the healed ulcer. The condition was quiescent and posterior synechiae were still present.

\section{MATERIALS AND METHODS}

The methods and media used were those of Cowan and Steel (1965) with some modifications. Indole, nitrate, methyl-red, Voges-Proskauer and $\mathrm{H}_{2} \mathrm{~S}$ tests were carried out both in the usual media and, because of the poor growth obtained in these media, also in the same media enriched with 0.5 per cent. yeast extract. Carbohydrate fermentation tests were carried out at $30^{\circ}$ and $37^{\circ} \mathrm{C}$ in Cystine Trypticase Agar medium (BBL), peptone water medium (Cowan and Steel), Hugh and Leifson's medium with 0.5 per cent. yeast extract, and solid nutrient agar slopes with added yeast extract $(0.5$ per cent.) and indicator.

\section{RESULTS}

A Gram-negative bacillus, which was oxidase-positive and catalase-negative, was isolated from the base of the ulcer before it had been treated with antibiotics. A stained smear of this swabbing showed numerous pus cells and Gram-negative intracellular bacilli. The properties of this organism are as follows.

Morphology. The organism was a non-motile bacillus approximately $1.0-2.0 \mu \mathrm{m}$ long and $0.5-0.75 \mu \mathrm{m}$ wide. It was Gram-negative with some tendency to show bipolar staining. No spores or capsules could be demonstrated.

Colonial appearance. The organism grew slowly, and after 24 hours' incubation at $37^{\circ} \mathrm{C}$ the colonies on blood agar were small $(0.1-0.5 \mathrm{~mm})$. The colony tended to grow downwards into the medium, resulting in indentations of the surface immediately beneath it. After $48-72 \mathrm{hr}$ the colonies were larger $(1-1.5 \mathrm{~mm})$ with an occasional colony twice this size. They were smooth and glistening when viewed in incident light with a stereomicroscope, and many showed a raised slightly opaque centre and a flat translucent periphery. The colonial appearance resembled that of Bacteroides corrodens. No haemolysis was evident after 24 hours' incubation, but after $48 \mathrm{hr}$ incomplete haemolysis was found on sheep blood agar, particularly in the area beneath the colony. Partial haemolysis was sometimes, but less frequently, evident also on horse blood agar.

Growth requirements. Growth was poor in peptone water, but was improved by the addition of blood or yeast extract. Growth occurred on nutrient agar, but the extent varied 
with different brands of commercially available media (Oxoid, Difco and BBL). Growth on freshly prepared veal infusion agar was good.

The organism grew aerobically, but only very poorly under anaerobic conditions. Growth was not noticeably improved by the addition of $\mathrm{CO}_{2}$, but unfortunately this characteristic was not investigated on first isolation. Growth occurred at $25^{\circ}, 30^{\circ}$ and $37^{\circ} \mathrm{C}$, but not at $20^{\circ}$ and $42^{\circ} \mathrm{C}$ after 14 days' incubation. Growth was most rapid at $30^{\circ} \mathrm{C}$.

TABLE I

Biochemical reactions of Moraxella isolated from a corneal abscess

\begin{tabular}{|c|c|c|c|}
\hline Catalase & - & Citrate utilisation & - \\
\hline Oxidase & + & $\mathrm{H}_{2} \mathrm{~S}$ production & - \\
\hline Penicillin sensitivity ( $0 \cdot 1$ unit) & + & Methyl red & - \\
\hline Indole & + & Voges-Proskauer & - \\
\hline Decarboxylases: & & Gelatin liquefaction & - \\
\hline Lysine & - & Urease & - \\
\hline Ornithine & - & Litmus milk & No change \\
\hline Phenylalanine deamination & - & Acid from glucose & + \\
\hline Nitrate reduction & - & $\begin{array}{l}\text { Hugh and Leifson's } \\
\text { O-F test }\end{array}$ & Fermentative \\
\hline
\end{tabular}

\section{TABLE II}

Characters of the new strain, and of Bacteroides corrodens and the saccharolytic species of Moraxella

\begin{tabular}{|c|c|c|c|c|}
\hline & Test strain & M. kingii* & B. corrodensi & $\begin{array}{l}\text { Moraxella sp. } \\
\text { (van Bijsterveld) }\end{array}$ \\
\hline $\begin{array}{l}\text { Catalase } \\
\text { Motility } \\
\text { Sensitivity to penicillin } \\
\text { Nitrate reduction } \\
\text { Saccharolytic } \\
\text { Phenylalanine deamination } \\
\text { Decarboxylases: } \\
\text { Lysine } \\
\text { Ornithine } \\
\text { Indole } \\
\text { DNA: percentage GC\& }\end{array}$ & $\begin{array}{l}\overline{-} \\
+ \\
\overline{+} \\
= \\
= \\
\overline{+} \\
49 \cdot 9\end{array}$ & $\begin{array}{c}- \\
\overline{+} \\
+ \\
\text { or }+ \\
+ \\
- \\
\overline{-} \\
\overline{4}\end{array}$ & $\begin{array}{l}- \\
+ \\
+ \\
+ \\
\cdots \\
+ \\
+ \\
56-58\end{array}$ & $\begin{array}{l}- \\
+ \\
+ \\
\frac{+}{+} \\
+ \\
- \\
- \\
+ \\
49\end{array}$ \\
\hline
\end{tabular}

* Henriksen and Bøvre (1968).

$\uparrow$ Hill, Snell and Lapage (1970).

van Bijsterveld (1970).

$\$$ The DNA base ratios were determined at the National Collection of Type Cultures, Colindale, except for that of van Bijsterveld's strain, which is quoted from his paper.

Biochemical characteristics. The biochemical properties of the organism are given in table I. Of the carbohydrates tested, acid was produced from glucose, sucrose, galactose (slowly), arabinose (slowly) and fructose (slowly). No acid was produced from lactose, xylose, mannitol and salicin. The fermentation reactions varied with the different basal media used.

\section{Discussion}

Comparison of this strain with published descriptions of B. corrodens (Hill, Snell and Lapage, 1970) and of other catalase-negative, oxidase-positive Moraxella species (Henriksen and Bøvre, 1968; van Bijsterveld, 1970) indicates that it most closely resembles van Bijsterveld's 
strain, from which it differs in its lack of motility, negative phenylalanine reaction and colonial appearance. It should be noted, however, that the results for the strains listed in table II were those stated in the original reports and that the strains were not re-tested in our laboratory in parallel with the strain reported in this paper.

Whether these differences are sufficient to consider this isolate a separate new species is as yet uncertain.

\section{SUMMARY}

A Gram-negative bacillus, provisionally identified as a moraxella, was isolated from an eye infection. The properties of this organism are given and compared with those of similar catalase-negative, oxidase-positive Gram-negative bacilli.

A subculture of this organism has been lodged with the National Collection of Type Cultures, Colindale, London.

The authors wish to thank Dr S. P. Lapage and Mr L. R. Hill of the N.C.T.C., Colindale, London, and Dr S. D. Henriksen, University of Oslo, Norway, for their kindness in examining this organism and expressing an opinion as to its identity. We also thank the Commonwealth Director-General of Health for permission to publish this paper.

\section{REFERENCES}

VAN Bijsterveld, O. P. 1970. New moraxella strain isolated from angular conjunctivitis. Appl. Microbiol., 20, 405.

Cowan, S. T., AND SteEL, K. J. 1965. Manual for the identification of medical bacteria, London.

HenRIKSEN, S. D., AND BøVRE, K. 1968. Moraxella kingii sp. nov., a haemolytic, saccharolytic species of the genus Moraxella. J. Gen. Microbiol., 51, 377.

Hirl, L. R., SNell, J. J. S., AND LAPAGE, S. P. 1970. Identification and characterisation of Bacteroides corrodens. J. Med. Microbiol., 3, 483. 